\title{
ВПЛИВ ОКСИЕТИЛЬОВАНИХ НОНІЛФЕНОЛІВ ТА Х ПОХІДНИХ НА ПРОЦЕСИ ЛІПОПЕРОКСИДАЦІ ТА ОКИСНО МОДИФІКАЦІ БІЛКІВ В ОРГАНІЗМІ ЩУРІВ
}

СД. І. Маракушин

\author{
Харківський національний медичний університет
}

РЕЗЮМЕ. У статті наведено дані про зміну стану процесів ліпопероксидаці та окисно модифікаці білків в організмі щурів за умов тривалого впливу оксиетильованих нонілфенолів та х похідних. Встановлено, що тривала інтоксикація оксиетильованими нонілфенолами та х похідними у дозах $1 / 10$ і $1 / 100$ ДЛ50 у сироватці крові щурів ініціює процеси оксидативного стресу з деструкцією білкових і ліпідних молекул. Продукти перекисного окислення ліпідів та окисно модифікаці білків внаслідок високо реактогенно здатності та вибірковості у біологічній ді можуть виступати в якості основного ланцюга, що лімітує стан стійкості організму до тривалого впливу оксиетильованих нонілфенолів та х похідних через зміну фізико-хімічних характеристик клітинних мембран, активності мембранолокалізованих та ліпідозалежних ферментів, реактивності нейроендокринно, імунно та інших систем організму. КЛЮЧОВІ СЛОВА: оксиетильовані нонілфеноли, дієнові кон'югати, ТБК-реактанти, шифові основи.

Вступ. Однією з ключових ланок механізму ді багатьох ксенобіотиків (КБ) на організм вважається активація вільнорадикальних процесів, що реалізується у вигляді перекисного окислення ліпідів (ПОЛ) та окисно модифікаці білків (ОМБ) [1-4]. Посилення цих процесів призводить, як правило, до порушення існуючого у фізіологічних умовах балансу між анти- та прооксидантами у бік підвищення активності останніх, тобто виникнення оксидативного стресу [5]. Неконтрольована генерація активних форм кисню при оксидативному стресі супроводжується порушенням структурно-функціонального стану клітинних мембран, процесів внутрішньоклітинного метаболізму, суттєвими змінами гомеостазу [6]. У зв'язку з цим, необхідність корекці оксидативного стресу, як одніє з причин виникнення екологічно обумовлено патологі в осіб, які тривалий час контактують з КБ, має суттєве значення.

До поширених на даний час КБ належать іоногенні детергенти, інтенсифікація виробництва яких зумовила забруднення ними водних об'єктів господарсько-питного та культурно-побутового призначення [7]. До числа високоперспективних у народногосподарському відношенні іоногенних детергентів належать оксиетильовані нонілфеноли (ОЕНФ) та х похідні - натрієві солі карбоксиметилатів оксиетильованих ізононілфенолів (KM-OEHФ). Останні характеризуються досить значними об'ємами синтезу, широким використанням (як основи промислового випуску пластмас, пінопластів, поліуретанів, миючих засобів, емульгаторів, антикорозійних препаратів, гідравлічних та охолоджуючих речовин тощо), надходженням до джерел питного водопостачання населення, та, завдяки цьому, можливим впливом на організм людини [8]. Стан процесів ПОЛ та ОМБ за умов тривалого впливу ОЕНФ та х похідних, дані щодо кількісного вмісту хпродуктів вивчені недостатньо, а саме х урахування $€$ необхідним для всебічного розкриття механізмів ді на організм та розроблення засобів х корекці .

Метою дослідження було визначення $y$ сироватці крові щурів вмісту дієнових кон'югатів, ТБК-реактантів, шифових основ та кетон-динітрофенілгідразонів за умов тривалого перорального впливу оксиетильованих нонілфенолів та х похідних у дозах 1/10 і 1/100 ДЛ50.

Матеріал і методи дослідження. У роботі використано зразки речовин з регламентованими Фізико-хімічними характеристиками: ОЕНФ з числом оксиетильованих груп 12 (ОЕНФ $\left.\Phi_{12}\right)$ та КМ-ОЕНФ 3 числом оксиетильованих груп 5 (КМ-OЕНФ) Експерименти проведено на статевозрілих щурахсамцях ліні WAG, масою 180-220 г. Утримання та маніпуляці над тваринами виконувались відповідно до основних принципів у сфері біоетики. Тварин піддавали пероральній затравці за допомогою зонда водними розчинами речовин щоденно одноразово протягом 45 діб у дозах $1 / 10$ і $1 / 100$ Д750. Середньолетальні дози (ДЛ50) складали для OEH $\Phi_{12}-3,4$ г/Кг, KM-OEHФ $\Phi_{5}-2,8$ г/Кг маси тіла. Тваринам контрольно групи вводили відповідні об'єми питно води. Дослідження показників проводили через 45 діб після початку експерименту. У кожній групі було по 15 тварин. Щурів декапітували, попередньо анестезуючи тіопенталом натрію. Вміст дієнових кон'югатів (ДК) визначали спектрофотометричним методом при 233 нм 3 попередньою екстракцією гептан-ізопропаноловою сумішшю [9]. Вміст ТБК-реактантів визначали за методом [10], що базується на реакці між малоновим діальдегідом і тіобарбітуровою кислотою, яка за умов високо температури та кислого середовища відбувається з утворенням забарвленого триметинового комплексу з максимумом поглинання при 532 нм. Шифові основи екстрагували сумішшю Фолча (хлороформ-метанол) з подальшим спектрофлуориметричним визначенням в хлороформ- 
Оеляди літератури, ориаінальні дослідження, поеляд на проблему

ному екстракті при довжині хвилі збудження 360 нм та довжині хвилі емісі 430 нм [11]. Оцінку інтенсивності окисно модифікаці білків сироватки крові проводили за допомогою модифікованого спектрофотометричного методу О. Є. Дубініно та співавт. [12], який ґрунтується на реакці взаємоді окислених амінокислотних залишків білків з 2,4-динітрофенілгідразином 3 утворенням 2,4-динітрофенілгідразонів (ДНФГ), які реєстрували при 356, 370 і 430 нм. Статистичний аналіз даних проводили з використанням комп'ютерного пакета прикладних програм для обробки статистично інформаці Statistica 6.1 (StatSoft, Inc., США). Первинне статистичне опрацювання даних починали з перевірки припущення про відповідність вибірок закону гаусівського розподілу. Кількісні ознаки, що мали нормальний розподіл, описували параметричними характеристиками - середнім значенням показника (M) та середнім квадратичним відхиленням (s); у разі відсутності нормального розподілу непараметричними - медіаною (Ме) та інтерквартильним розмахом. Для порівняння двох нормальних розподілів застосовували t-критерій Стьюдента. Якщо принаймні один з розподілів не був нормальним, то для порівняння незалежних вибірок застосо- вували критерій Манна-У тні. За критичний рівень значущості при перевірці статистичних гіпотез приймали $\mathrm{p}<0,05$.

Результати й обговорення. На 45-ту добу ді КМ-ОЕНФ і ОЕНФ $_{12}$ у дозі $1 / 10$ ДЛ50 в сироватці крові щурів спостерігалося статистично значуще $(p<0,002)$, порівняно з контролем, підвищення вмісту ДК, відповідно в 1,5 і 1,3 раза (табл. 1). Для дози 1/100 ДЛ50 збільшення вмісту ДК виявилося недостовірним ( $p=0,16$ та $p=0,11)$. Крім того, у сироватці крові щурів при тривалій ді речовин у дозі $1 / 10$ ДЛ50 визначалося зростання $(\mathrm{p}<0,002)$ рівня ТБК-реактантів: в 1,8 і 1,7 раза відповідно для КМ-ОЕНФ, і ОЕНФ $\Phi_{12}$ (табл. 1). Слід підкреслити, що доза 1/100 ДЛ50 по відношенню до сироваткових ТБК-реактантів виявилася діючою лише для КМ-ОЕНФ $\mathrm{p}=0,009)$. Для шифових основ також відмічалося статистично значуще, порівняно з контролем, підвищення майже в 3 рази $(p<0,001)$ в результаті ді речовин у дозі $1 / 10$ ДЛ50. Така сама динаміка зміни цього показника спостерігалася й за умов впливу 1/100 ДЛ50: збільшення $(p<0,001)$ при цьому становило 2,9 і 2,2 раза відповідно для КМOEHФ ${ }_{5}$ i OEHФ $\Phi_{12}$

Таблиця 1. Вміст продуктів перекисного окислення ліпідів у сироватці крові щурів на 45 добу впливу

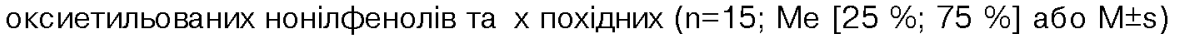

\begin{tabular}{|l|l|c|c|c|c|}
\hline \multirow{2}{*}{ Речовина } & \multicolumn{1}{|l|}{$\begin{array}{c}\text { Доза, } \\
\text { ДЛ50 }\end{array}$} & $\begin{array}{c}\text { Дієнові } \\
\text { кон'югати, } \\
\text { мкмоль/л }\end{array}$ & $\begin{array}{c}\text { ТБК-реактанти, } \\
\text { мкмоль/л }\end{array}$ & $\begin{array}{c}\text { Шифові основи, } \\
\text { ум.од/мл }\end{array}$ & $\begin{array}{c}\text { Шифові основи/ } \\
\text { (ДК+ТБК-реактанти) }\end{array}$ \\
\hline ОЕНФ 12 & $1 / 10$ & $5,5[5,2 ; 7,0]$ & $4,0 \pm 1,25$ & $4,6 \pm 1,39$ & $0,46 \pm 0,174$ \\
& & $\mathrm{p}=0,002$ & $\mathrm{p}=0,002$ & $\mathrm{p}<0,001$ & $\mathrm{p}<0,001$ \\
& $1 / 100$ & $5,2[3,7 ; 5,8]$ & $3,2 \pm 1,12$ & $3,5 \pm 1,04$ & $0,42[0,31 ; 0,5]$ \\
& & $\mathrm{p}=0,16$ & $\mathrm{p}=0,09$ & $\mathrm{p}<0,00,001$ \\
\hline КМ-ОЕНФ & $1 / 10$ & $6,5 \pm 1,35$ & $4,2 \pm 1,39$ & $4,6[3,9 ; 5,9]$ & $0,5 \pm 0,149$ \\
& & $\mathrm{p}<0,001$ & $\mathrm{p}=0,002$ & $\mathrm{p}<0,001$ & $\mathrm{p}<0,001$ \\
& $1 / 100$ & $5,2 \pm 1,57$ & $3,7 \pm 1,23$ & $4,6 \pm 0,83$ & $0,54 \pm 0,154$ \\
& & $\mathrm{p}=0,11$ & $\mathrm{p}=0,009$ & $\mathrm{p}<0,001$ & $\mathrm{p}<0,001$ \\
\hline Контроль & & $4,3 \pm 1,19$ & $2,3[1,9 ; 3,4]$ & $1,6 \pm 0,52$ & $0,24 \pm 0,081$ \\
\hline
\end{tabular}

Примітка. $\mathrm{p}$ - рівень значущості порівняно з контролем.

Для з'ясування динаміки спрямованості процесів ПОЛ розраховували коефіцієнт співвідношення шифові основи/(ДК+ТБК-реактанти) (табл. 1). Результати показали, що значення цього коефіцієнта за умов ді ОЕНФ $\Phi_{12}$ і КM-OЕНФ ${ }_{5}$ у дозах $1 / 10$ і 1/100 ДЛ50 статистично значуще $(p<0,001)$, порівняно з контролем, збільшувалося в середньому в 2 рази. Це, у свою чергу, переконливо свідчить про спрямованість процесів ПОЛ у бік утворення токсичних кінцевих продуктів - шифових основ. Однією з найімовірніших причин зниження рівня первинних і вторинних продуктів ПОЛ на тлі збільшення рівня кінцевих продуктів може бути виснаження активності первинних «аварійних» антиоксидантів. Отримані результати добре узгоджуються з даними літератури щодо індукованого впливу іоногенних детергентів на пероксидні процеси в організмі теплокровних тварин [13]. Крім того, літературні джерела свідчать про можливість ОЕНФ брати участь в окисно-відновлювальних процесах, викликати збільшення активних Форм кисню та розвиток оксидативного стресу на тлі виснаження антиоксидантних ресурсів [8].

На 45-ту добу впливу OEHФ $\Phi_{12}$ та KM-OEH $\Phi_{5}$ у дозах 1/10 і 1/100 ДЛ50 спостерігалася активація процесів ОМБ, що підтверджувалося статистично значущим, порівняно з контролем, підвищенням у сироватці крові вмісту нейтральних альдегідДНФГ і кетон-ДНФГ (356 і 370 нм), а також основних альдегід-ДНФГ (430 нм) (табл. 2). Слід під- 
Оеляди літератури, оригінальні дослідження, поеляд на проблему

креслити, що для контрольно групи тварин також характерна наявність ДНФГ, що свідчить про перебіг цих процесів за фізіологічних умов.

Крім того, в контрольній групі щурів рівень ДНФГ нейтрального характеру в 9-11 разів перевищував вміст ДНФГ основного характеру, що збігається $з$ даними літератури [12]. Тривалий вплив ОЕНФ $\Phi_{12}$ та КМ-ОЕНФ сприяв статистично значущому $(p<0,001)$, порівняно з контролем, зростанню рівня ДНФГ нейтрального характеру в 1,5-2 рази. Для дози 1/100 ДЛ50 зберігалася така сама тенденція, але вона була менш виразна: вміст нейтральних ДНФГ збільшувався в 1,2-1,9 раза ( $p<0,024)$. На цьому тлі спостерігалося статистично достовірне зростання рівня альдегід-ДНФГ основного характеру при 430 нм: в середньому в 2 рази при ді 1/10 ДЛ50 $(p<0,001)$ та 1,5 раза при ді 1/100 ДЛ50 (p<0,014). Істотні зміни рівня основних альдегід-ДНФГ можуть бути пов'язані з посиленим глікозилюванням білків за умов токсичного стресового стану. Доведено, наприклад, збільшення вмісту продуктів неферментативного глікозилювання білків при оксидативному стресі [14]. У цілому, збільшення у сироватці крові експериментальних тварин рівня окисномодифікованих білків може свідчити про виснаження резервно-адаптаційних можливостей організму за умов тривалого впливу ОЕНФ та х похідних [15].

Таблиця 2. Вміст альдегід- та кетондинітрофенілгідразонів у сироватці крові щурів на 45-добу впливу

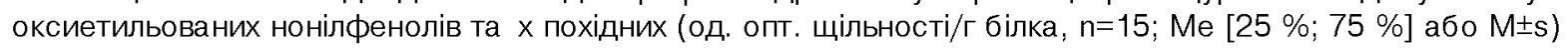

\begin{tabular}{|l|l|c|c|c|}
\hline \multicolumn{1}{|c|}{ Речовина } & Доза, ДЛ50 & 356 нм & $370 \mathrm{HM}$ & $430 \mathrm{HM}$ \\
\hline ОЕНФ $_{12}$ & $1 / 10$ & $56,1 \pm 6,68$ & $54,1 \pm 5,56$ & $7,0[6,4 ; 8,8]$ \\
& & $\mathrm{p}<0,001$ & $\mathrm{p}<0,001$ & $\mathrm{p}<0,001$ \\
& $1 / 100$ & $40,0[38,5 ; 42,3]$ & $45,1[39,5 ; 47,0]$ & $4,7 \pm 1,32$ \\
& & $\mathrm{p}<0,001$ & $\mathrm{p}<0,001$ & $\mathrm{p}=0,003$ \\
\hline КМ-ОЕНФ & & $62,1 \pm 6,90$ & $50,0[46,9 ; 53,8]$ & $6,5 \pm 2,46$ \\
& $1 / 10$ & $\mathrm{p}<0,001$ & $\mathrm{p}<0,001$ & $\mathrm{p}<0,001$ \\
& \multirow{2}{*}{$1 / 100$} & $52,6 \pm 6,38$ & $40,0[36,7 ; 45,0]$ & $4,2 \pm 1,16$ \\
& & $\mathrm{p}<0,001$ & $\mathrm{p}=0,024$ & $\mathrm{p}=0,014$ \\
\hline Контроль & & $27,6 \pm 8,80$ & $34,0[28,7 ; 42,1]$ & $3,1 \pm 1,16$ \\
\hline
\end{tabular}

Примітка. р - рівень значущості порівняно з контролем.

Висновки. 1. На тлі тривало інтоксикаці ОЕНФ та х похідними у дозах 1/10 і 1/100 ДЛ50 у сироватці крові щурів ініціюються процеси оксидативного стресу з деструкцією білкових і ліпідних молекул, що відображається підвищенням рівня дієнових кон'югатів, ТБК-реактантів, шифових основ та динітрофенілгідразонів.

2. Продукти перекисного окислення ліпідів та окисно модифікаці білків внаслідок високо реактогенно здатності та вибірковості у біологічній ді можуть виступати в якості основного ланцюга, що лімітує стан стійкості організму до тривалого впливу ОЕНФ та х похідних через зміну фізико-хімічних характеристик клітинних мембран, активності

\section{ЛІТЕРАТУРА}

1. Ксенобіотики: накопичення, детоксикація та виве дення з живих організмів / [Цудзевич Б. О., Столяр О. Б., Калініна І. В., Юкало В. Г.]. - Тернопіль : Видавництво ТНТУ ім. І. Пулюя, 2012. - 384 c.

2. Новиков К. Н. Свободно-радикальные процессы в биологических системах при воздействии факторов окружающей среды / К. Н. Новиков, С. В. Котелевцев, Ю. П. Козлов. - М. : РУДН, 2011. - 199 с.

3. Резуненко Ю. К. Вплив поліолів на основі гліцеролу, етилен- і пропіленгліколю на процеси вільнорадикального окислення в організмі щурів / Ю. К. Резуненко В. О. Прокопов, В. І. Жуков // Світ медицини та біологі . 2012. - № 2. - C. 143-146. мембрано-локалізованих та ліпідозалежних ферментів, реактивності нейроендокринно, імунно та інших систем організму.

3. Інтенсифікація процесу перекисного окислення ліпідів і окисно модифікаці білків $\epsilon$ однією 3 патогенетичних ланок механізмів ді ОЕНФ та $x$ похідних, що необхідно враховувати при розробленні засобів х корекці .

Перспективи подальших досліджень. У подальшому планується провести комплекс досліджень, спрямованих на вивчення активності системи антиперекисного та антирадикального захисту при тривалому впливі ОЕНФ та $\mathrm{x}$ похідних.

4. Окислительная модификация белков: проблемы и перспективы исследования / Л. Е. Муравлева, В. Б. Молотов-Лучанский, Д. А. Клюев [и др.] // Фундаментальные исследования. - 2010. - № 1. - С. 74-78.

5. Окислительный стресс: патологические состояния и заболевания / [Е. Б. Меншикова, Н. К. Зенков, В. 3. Ланкин та ін. . - М. : АРТА, 2008. $-284 \mathrm{c}$.

6. Часовских Н. Ю. Апоптоз и окислительный стресс / Н. Ю. Часовских, Н. В. Рязанцева, В. В. Новицкий. - Томск : Печатная мануфактура, 2009. - 148 c.

7. Детергенти сучасності: технологія виробництва, екологія, економіка використання / [В. А. Бурлака, Г. Б. Руденко, І. Г. Грабар, А. Д. Біба]. - Ж. : ЖДТУ, 2004. - 745 с. 
Оеляди літератури, ориаінальні дослідження, поеляд на проблему

8. Научные основы обоснования прогноза потенциальной опасности детергентов в связи с регламентацией в воде водоемов / [Цыганенко А. Я., Жуков В. И., Щербань Н. Г. и др.]. - Белгород, 2001. - 442 с.

9. Косухин А. Б. Экстракция липидов смесью гептанизопропанол для определения диеновых конъюгатов / А. Б. Косухин, Б. С. Ахметова // Лабораторное дело. 1987. - № 6. - С. 335-337.

10. Федорова Т. Н. Реакции с тиобарбитуровой кислотой для определения малонового диальдегида крови методом флюориметрии / Т. Н. Федорова, Т. С. Коршунова, Э. Г. Ларский // Лабораторное дело. - 1983. № 3. - C. 25-28.

11. Rice-Evans C. A. Techniques in free radical research / C. A. Rice-Evans, A. T. Diplock, M.C.R. Symons. - Elsevier, 1991. - $309 \mathrm{p}$.

12. Окислительная модификация белков сыворотки крови человека, метод ее определения / Е. Е. Дубинина,
С. О. Бупмистров, Д. А. Ходов [и др.] // Вопросы медицинской химии. - 1995. - Т. 41, № 1. - С. 24-26.

13. Медико-биологические аспекты проблемы охраны водных объектов от загрязнения поверхностноактивными веществами / [Р. И. Кратенко, Ю. К. Резуненко, О. В. Зайцева и др.] ; под ред. В. И. Жукова. - Х. : Торнадо, 2000. - $394 \mathrm{c.}$

14. Munch $\mathrm{G}$. Enhanced glycation of hemoglobin and plasma proteins is associated with increased lipid peroxide levels in non-diabetic hypertensive subjects / G. Munch, R. Keis, A. Wessels // Arch. Med. Res. - 2007. - Vol. 38, № 8 . - P. 822-826.

15. Токсикологические последствия окислительной модификации белков при различных патологических состояниях (обзор литературы) / Ю. И. Губский, И. Ф. Беленичев, Е. Л. Левицкий [и др.] // Проблемы токсикологии. - 2005. - № 3. - С. 20-27.

\section{THE INFLUENCE OF OXYETHYLIZED NONYLPHENOLS AND THEIR DERIVATIVES ON THE PROCESSES OF LIPOPEROXIDATION AND OXIDIZING MODIFICATION OF PROTEINS IN ORGANISM OF RATS}

\section{Kharkov national medical university}

CD. I. Marakushin

SUMMARY. In the article the data are resulted about disorder of the state of lipoperoxidation processes and oxidizing modification of proteins in the rats organism under the long-term influence of oxyethylized nonylphenols and their derivatives. It is revealed, that the long-term intoxication by oxyethylized nonylphenols and their derivatives at doses of 1/10 and 1/100 DL50 in the serum of rats blood initiate the processes of oxidative stress with destruction of protein and lipidic molecules. The products of lipid peroxidation and oxidizing modification of proteins as a result of high reactogenic ability and selectivity in biological action can play the role of a basic chain, that limits the state of steadiness of an organism to the long-term influence of oxyethylized nonylphenols and their derivatives through the change of physical and chemical properties of cellular membranes, activity of membra ne-localized and lipiddepending enzymes, reactivity of neuroendocrinous system, immune and other systems of an organism.

KEY WORDS: oxyethylized nonylphenols, diene conjugates, TBA-reactants, Schiff bases. 